\title{
A Quantitative Analysis of Surface Changes on an Abandoned Forest Road in the Lejowa Valley (Tatra Mountains, Poland)
}

\author{
Joanna Fidelus-Orzechowska ${ }^{1, *}$, , Dariusz Strzyżowski ${ }^{2}$, Jarosław Cebulski ${ }^{3}(\mathbb{D}$ and \\ Dominika Wrońska-Wałach ${ }^{2}$ \\ 1 Institute of Geography, Pedagogical University of Cracow, Podchorążych 2, 30-084 Cracow, Poland \\ 2 Institute of Geography and Spatial Management, Jagiellonian University, Gronostajowa 7, 30-387 Cracow, \\ Poland; dariusz.strzyzowski@doctoral.uj.edu.pl (D.S.); dominika.wronska-walach@uj.edu.pl (D.W.-W.) \\ 3 Institute of Geography and Spatial Organization, Polish Academy of Sciences, sw. Jana 22, 31-018 Cracow, \\ Poland; cebulski@zg.pan.krakow.pl \\ * Correspondence: joanna.fidelus-orzechowska@up.krakow.pl
}

Received: 28 September 2020; Accepted: 15 October 2020; Published: 21 October 2020

check for updates

\begin{abstract}
The main aim of this research was to determine the magnitude of geomorphologic changes within a section of a forest road. The research was carried out in the Lejowa Valley in the Tatra Mountains. The measurements of the surface of the road were performed using a RIEGL VZ-4000 terrestrial laser scanner (TLS). TLS models for 2017, 2018, and 2019 served as the basis for the determination of quantitative and spatial relief transformations. The net annual change on the studied road within the first period equaled $-884 \mathrm{~m}^{3} \mathrm{ha}^{-1}$ year $^{-1}$, and for the second period $-370 \mathrm{~m}^{3} \mathrm{ha}^{-1}$ year $^{-1}$. Changes across the accumulation fan ranged from $-265 \mathrm{~m}^{3} \mathrm{ha}^{-1} \mathrm{year}^{-1}$ to $+36 \mathrm{~m}^{3} \mathrm{ha}^{-1}$ year $^{-1}$. The average rate of erosion on the studied abandoned road is similar, and sometimes even greater than that on roads which are still in use. Our research shows that improper road location may lead to irreversible changes to the natural environment. The planning of a forest road must take into account natural conditions, otherwise progressive relief transformations may lead to significant surface changes and the road may be excluded from use.
\end{abstract}

Keywords: forest roads; erosion rates; relief transformation; terrestrial laser scanning (TLS); Tatra Mountains

\section{Introduction}

Forest management is one of the most important factors influencing the intense transformation of relief in forested areas [1,2]. Forest roads may cause significant changes in water and matter circulation on a mountain slope, which has been shown in many places all over the world, including the Tatra Mountains in Poland [3], the Olympic Mountains in the USA [4,5], tropical forests on the Malay Peninsula [6-8], Western Cascades in the USA [9], Penteli Mountain in Greece [10], and Rio das Pedras watershed valley in Brazil [11]. The construction and use of forest roads may contribute to the development of numerous erosional and depositional landforms including erosional cuts, landslides, and accumulation fans. This is confirmed by research work performed in Poland, and more specifically in the Karkonosze Mountains [12], Gorce Mountains [13], Beskidy Mountains [1], and Tatras Mountains [3] as well as in other locations in the world, for example in the Olympic Mountains, USA [4], Cascade Range, USA [14], in the mountain areas of northeastern Italy [15,16], and on the Darab Kola Mountain in Iran [17]. The research used, among others, geomorphological mapping, repeated measurements within cross-section profiles, modeling, and field experiments. 
Excessive fragmentation of the slope system due to the establishment of new roads and skid trails, activation of geomorphologic processes, and hydrologic changes may cause irreversible transformation of land relief [18]. The development of deep erosional incisions may occur even within a single season, which may be the result of considerable forest management work, but also of an improperly engineered mountain slope road $[3,12]$. This is especially important in protected environmental areas, where maintaining the balance between human impact and the natural functioning of a given area is one of the more important goals $[19,20]$. Allowing land use by the local community while maintaining biodiversity is of the utmost importance in protected environmental areas where economic activity such as logging is allowed [21]. Sustainable development and protection of forest resources should be the leading goals in forest management in mountain areas [22].

The implementation of new methods allowing determining changes on forest roads and logging roads on hillslopes with better accuracy should be one of the more important tasks in the management of forest areas. The use of LiDAR data to identify relief transformation on forest roads and logging roads allows taking a broader look at their relief evolution [23-26]. Comparison of terrestrial laser scanning (TLS) data allows determining changes with an accuracy of $3 \mathrm{~mm}$ to $10 \mathrm{~mm}[27,28]$. However, due to the limited range, especially in mountain areas, these investigations focus on short sections of road, for example $150 \mathrm{~m}$ [27], $530 \mathrm{~m}$ [28], $100 \mathrm{~m}$ [29], and $684 \mathrm{~m}$ [26]. An analysis of forest roads over a wider area is possible with the use of aerial laser scanning (ALS) data, although the measurements are less accurate [30,31]. Analysis of LiDAR data has shown that the density of forest roads and logging roads in the Polish Carpathians is one of the highest, as documented in the research literature, which considerably exceeds all recommended values [31]. The density of forest roads, their geomorphologic location, and their type of use may have a significant impact on the transformation of the natural environment [19,32]. This is why research is necessary, especially on a local scale, such that will provide a better understanding of the overall situation and will allow to identify circumstances and actions causing the intensification of geomorphologic processes [22,33]. Such research may be useful to create guidelines and instructions for proper design, use, and management of forest roads and skid trails.

The studied section of the road was selected based on a geomorphological mapping of forest roads the results of which were published in 2018 [3]. In this research we mapped forest roads sections, $6.2 \mathrm{~km}$ in total. Our research indicated that the significant relief transformations within forest roads are mainly dependent on the number of subsurface flow interception features within cutslopes. Such sections are frequently located in places where the road crosses a convergence area [3]. That investigation showed that the identified section of the road had become transformed the most and it was already abandoned in the third year of usage. This is why it was decided to conduct a detailed study with the use of terrestrial laser scanning (TLS). The aim of this research was to determine the magnitude of geomorphologic changes occurring within the selected section of the abandoned forest road. Specific goals included: (i) the determination of quantitative and spatial changes on the road section and accumulation fan, (ii) the determination of the relationship between the mean flow velocity and the magnitude of net erosion within selected forest road sections.

\section{Study Area}

The investigated section of a road was selected based on the previous research in which roads located in the Lejowa, Jaroniec, and Kościeliska valleys were studied (Figure 1a) [3]. Those roads are located in the area where a catastrophic wind event in December 2013 caused extensive damage to tree stands [34], and some of them were created during extensive forest works which were begun in 2014 and 2015. The highest erosion was noted on the road located in the Lejowa Valley, which was constructed in 2014, however, it was abandoned in 2016 due to intense transformation of land relief [3] (Figure 2a-f). The lowest part of this road (Figure 1c) encountered the greatest surface changes and it was the subject of this work. These relief transformations were due to intensive rainfall, which occurred 
in 1.07.2016. Maximum precipitation intensity reached $62.6 \mathrm{~mm}$ over 5 hours (data source: the Institute of Meteorology and Water Management - National Research Institute, Poland) (Figure 2b,c).

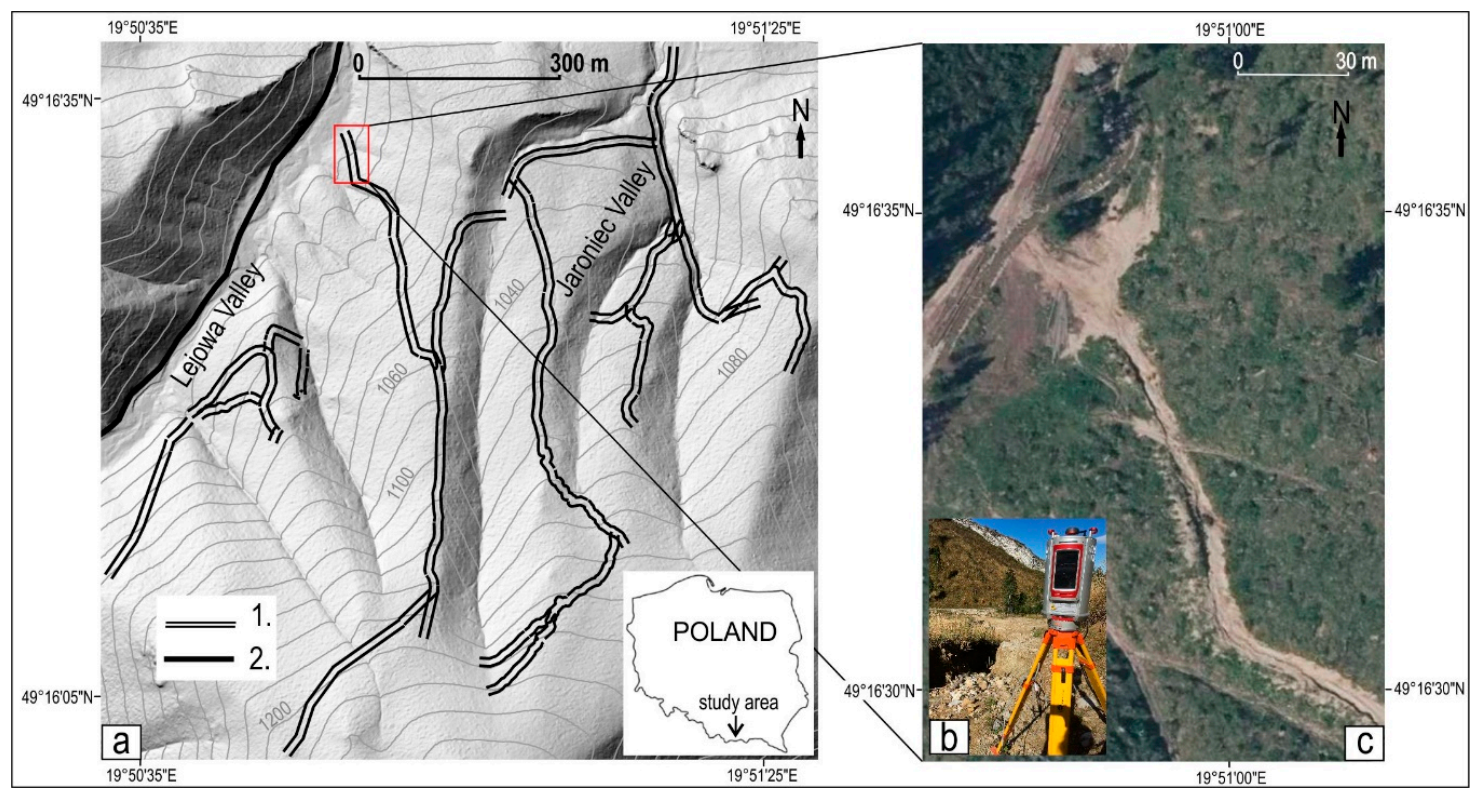

Figure 1. Location of studied forest roads in the Lejowa and Jaroniec valleys (a), explanations: road sections identified by geomorphological mapping (1), tourist road in the Lejowa Valley (2). The RIEGL VZ-4000 scanner used to scan the road (b). The studied road on an orthophotomap taken in 2019 (data source: www.geoportal.gov.pl) (c).

The studied road is located within sedimentary rocks and runs primarily over an area formed of conglomerate. The average annual precipitation amount in the study area ranges from 1200 to $1400 \mathrm{~mm}$ [35]. The average total precipitation from June to September for the moderately cool elevation, at which the investigated road section is located, is $610 \mathrm{~mm}$ [36]. The average annual temperature ranges from 4 to $6{ }^{\circ} \mathrm{C}$, and the number of days with snow cover is in the range from 80 to 120 days [37]. There were differences in the amount of precipitation both in annual and in the summer season in the studied period (according to the Institute of Meteorology and Water Management - National Research Institute) (Table 1). The investigated road is located in the landscape protection zone of the Tatra National Park, where logging is allowed.

Table 1. Annual and summer season sum of precipitation between 2017 and 2019 (Data source: the Institute of Meteorology and Water Management - National Research Institute).

\begin{tabular}{ccc}
\hline \multirow{2}{*}{ Year } & \multicolumn{2}{c}{ Precipitation (mm) } \\
\cline { 2 - 3 } & Annual Value & from June to September \\
\hline 2017 & 1318.7 & 678.9 \\
2018 & 1196.2 & 824.7 \\
2019 & 950.6 & 401.7 \\
\hline
\end{tabular}



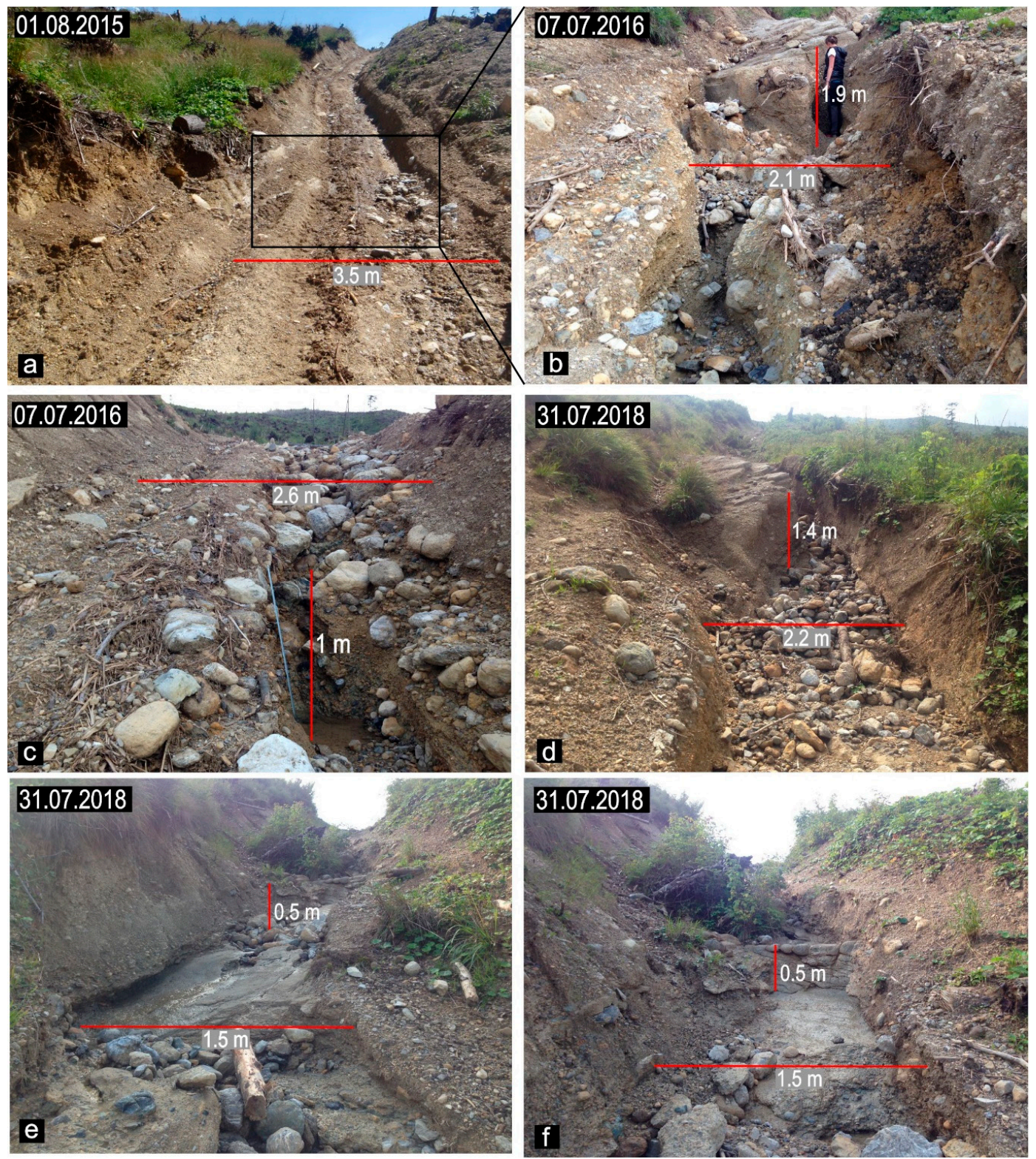

Figure 2. Changes on the surface of the studied road, explanations: the road in use in the first year after its construction (a); deep incisions formed after heavy rainfall, which contributed to exclusion the road from usage $(\mathbf{b}, \mathbf{c})$; strong relief transformations on the road two years after exclusion the road from usage $(\mathbf{d}-\mathbf{f})$.

\section{Methods}

\subsection{Analysis of Digital Elevation Models}

Terrestrial laser scanning (TLS) of the selected road section was performed between 2017 and 2019 (Figure 1b). The measurement of the surface of the road was performed using a RIEGL VZ-4000 TLS terrestrial laser scanner with a spatial data acquisition speed of about 222,000 pts. $\mathrm{s}^{-1}$. The measurements were performed three times (31 August 2017, 31 July 2018, 1 October 2019). The precision of the scanner was $10 \mathrm{~mm}$, and its accuracy was $15 \mathrm{~mm}$. Point clouds derived from TLS were then processed using RiSCAN PRO software including the multi-station adjustment (MSA) module, which can generate planes from point clouds and then aligns them based on similarity and spatial distribution. The resulting poly-data objects were used by the RIEGL multi-station adjustment tool for automatic fine alignment using best-fit least-squares iteration. The processed data were then converted into the LAS 1.2 format 
(special format for point clouds from LiDAR). In the next step in ArcGIS 10.2.2 (ESRI, Redlands, CA, USA) software data LAS 1.2 format was converted to raster data. The raster data so prepared, was with a resolution of $0.05 \mathrm{~m}$.

In order to determine the magnitude of changes resulting from the road construction process, the airborne laser scanning (ALS) model of 2013 was compared with the TLS model prepared in 2017. The 2013 ALS was obtained from Poland's National Protection Against Extreme Hazards (Polish acronym: ISOK) project. The adjustment of the $x$ and $y$ coordinates was made on the basis of a manual adjustment based on the detailed topography of the area in the immediate vicinity of the road (small denudation valley locations, the lower edge of the slope). In order to adjust the $z$ coordinate (height), the raster model was changed into a vector model (points) and the $z$ coordinates from the ALS model were compared with the $z$ coordinates of the TLS model. On this basis, the functional relationship $\mathrm{R}^{2}=0.99$ was determined.

TLS models for 2017, 2018, and 2019 served as the basis for the determination of quantitative and spatial changes resulting from the activity of natural geomorphologic processes on the abandoned road. A DEM of difference (DoD) was created using ArcGIS 10.2.2 software, which involved a comparison of the differences between DEMs from different measurement sessions. The DEMs of difference (DoD) were made in ArcGIS 10.2.2 software using the map algebra and raster calculator tools. The first DoD was created for the period 2017-2018, and the second for the period 2018-2019. In order to determine spatial differences in the changes the entire studied road was divided into 24 equal-length segments, each about $3 \mathrm{~m}$ long (Figure 3).

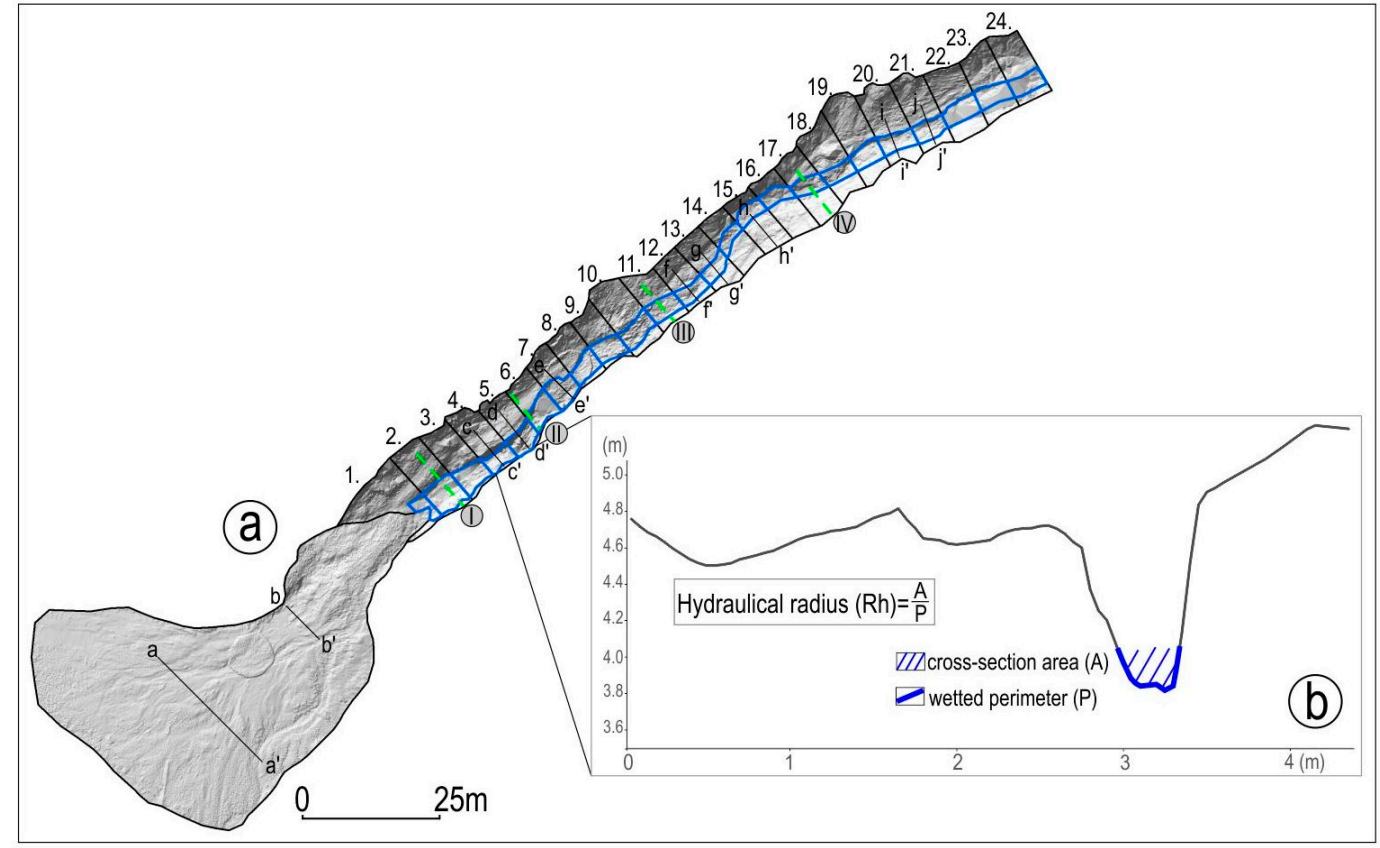

Figure 3. Segments (1-24) of the investigated road with the erosion gully marked by a blue line, cross-section profiles (I-IV) marked by dashed green, lines, and (a-j) marked by thin black lines (a). An example of the cross-section profile within one road segment (4) with the average level of water during a rainfall event marked $(\mathbf{b})$.

The magnitude of erosion and accumulation was determined for each of the segments and for the accumulation fan formed at the road's entrance. Moreover, in order to visualize the local magnitude of changes on each given road segment, 10 cross profiles were created based on the TLS models. Those cross-section profiles (10) were chosen to be along the entire road and in zones where significant changes could be observed. In addition, we have determined four cross profiles before and after the 
forest road construction to show the size of the road cut into the slope. We selected the road cross profiles which represented different road development.

\subsection{Flow Velocities Analysis}

In order to determine the relationship between the mean flow velocity and the magnitude of net erosion the average flow velocity was calculated for 2017 for 24 road segments (Figure 3). The flow velocity $(\mathrm{V})$ was calculated using the Manning formula: $V=1 / n^{*} R 2 / 3^{*} s 1 / 2$, where $V$ is the average flow velocity $\left(\mathrm{m} \mathrm{s}^{-1}\right), \mathrm{n}$ is the stream bottom roughness coefficient [38], $\mathrm{Rh}$ is the hydraulic radius (m), and $\mathrm{s}$ is the slope of the hydraulic grade line $\left(\mathrm{m} \mathrm{m}^{-1}\right)$.

The roughness coefficient was assumed to be 0.17 for segments with existing rock outcrops (segments 1-18) and 0.35 for segments with large gravels and boulders in the substratum (segments 19-24). A cross-section profile was made within each of the 24 plots. Within the profiles, zones of the highest flow concentration were identified. Then, on this basis, the extent of the erosion gully within which the maximum flow concentration takes place during rainfall events was determined (Figure 3). The hydraulic radius was determined on the basis of individual profiles and by field observations of the road profile filling during rainfall. The correlation $(p=0.05)$ between the average flow velocity and the magnitude of annual net erosion within the designated erosion gully was calculated (Figure 3). Before conducting the statistical analysis, the normality test (Shapiro-Wilk) was conducted. Due to the fact that the values presenting the annual net erosion did not have a normal distribution, a transformation $\left(\log _{10}\right)$ was applied. All statistical analyses were performed in the Statistica 13.

\section{Results}

The length of the detailed studied subsection of the road was $120 \mathrm{~m}$. The studied road is located at elevations ranging from 926 to $950 \mathrm{~m}$ a.s.l. The average slope of the road is 19 degrees, with a maximum of 22 degrees. The average width of the road is $3 \mathrm{~m}$ (Figure 2a). The greatest relief transformation after abandonment of the studied road occurred on July 18-19, 2018 and was associated with a heavy rainfall event (the 24-hour rainfall total was $118.8 \mathrm{~mm}$ ) (Figure 2b). In 2019, the total precipitation in the analyzed period was only half of what it had been a year earlier. Consequently, the degree of relief transformation was significantly lower than that in 2018.

\subsection{Changes at Cross-Section Profiles of the Forest Road in the Period 2013-2017}

Relief transformation in the period 2013-2017 was related to the construction of the studied road as well as its use and increased level of activity of geomorphologic processes on the hillslope.

Deep incisions in the surface of the road are visible at all measurement sites (Figure 4). On average, the road surface was cut into the slope between $0.77 \mathrm{~m}$ (profile c) to $1.5 \mathrm{~m}$ (profile b), and the maximum depth was $1.3 \mathrm{~m}$ (profile c), $1.5 \mathrm{~m}$ (profile a), $1.8 \mathrm{~m}$ (profile d), and $2.5 \mathrm{~m}$ (profile b). An embankment formed by the material removed while the road was being constructed was also observed. The average thickness of that deposited material was from $0.3 \mathrm{~m}$ (profile c) to $1 \mathrm{~m}$ (profile d).

\subsection{Changes at Cross-Section Profiles along the Forest Road in the Period 2017-2019}

All the data presented for the period 2017-2019 refer to relief transformation that occurred only due to the action of natural geomorphologic processes (Figure 5). The largest relief transformation occurred in 2017-2018 along the lowest located road segment (profile $\mathrm{cc}^{\prime}, \mathrm{dd}^{\prime}$ ). In this period the average decrease in elevation of the surface of the road within profiles $\mathrm{cc}^{\prime}$ and dd' was $0.24 \mathrm{~m}$ and $0.32 \mathrm{~m}$, respectively. However, the average lowering of the road surface within deep incision located within those profile was $1.34 \mathrm{~m}\left(\mathrm{cc}^{\prime}\right)$ and $0.83 \mathrm{~m}$ (profile $\mathrm{dd}^{\prime}$ ), the maximum lowering was $1.7 \mathrm{~m}$ (profile $\left.\mathrm{cc}^{\prime}\right)$. In the period 2018-2019, changes within the profiles were much smaller and accumulation dominated. 

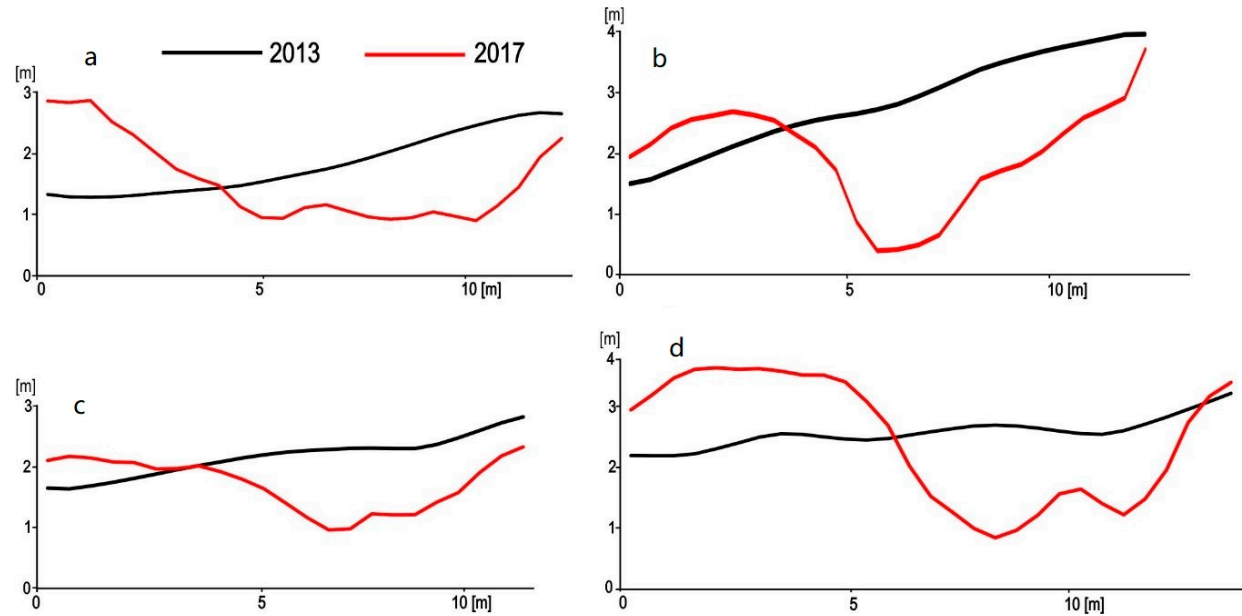

Figure 4. Cross section profiles within the analyzed forest road with embankments within the left-hand side of each profile; black line shows year 2013 (before road construction), red line shows year 2017 (after road abandonment). The road surface (red line) without clearly developed erosive cuts (a,c). The road surface (red line) with clearly developed erosive cuts $(\mathbf{b}, \mathbf{d})$. Locations of the profiles are marked on Figure 3.
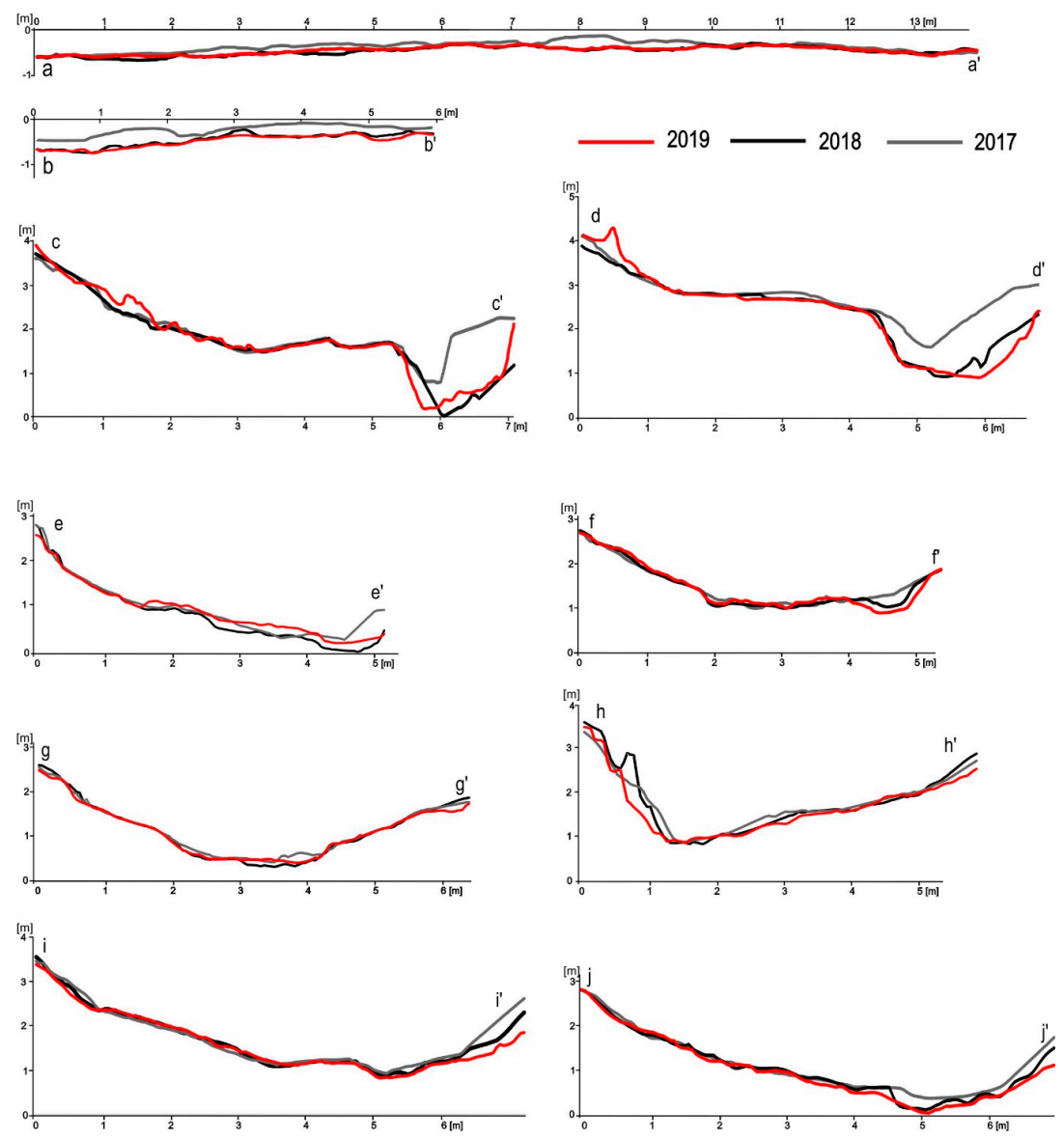

Figure 5. Changes at selected cross profiles along the studied forest road and within accumulation fan in the years 2017-2019. Changes in the accumulation fan at the end of the road (a,b). Changes in the erosion gully in the lower part of the road $(\mathbf{c}, \mathbf{d})$. Changes within the road surface without clearly developed erosion cuts $(\mathbf{e}-\mathbf{j})$. Locations of the profiles are marked on Figure 3. 
Changes at subsequent measurement sites along the studied road were significantly smaller in the periods under analysis. The maximum deepening in the period 2017-2018 was in the range from 0.32 (profile $\mathrm{ff}^{\prime}$ ) to $0.71 \mathrm{~m}$ (profile ee'). However, in the period 2018-2019 the maximum deepening ranged from 0.2 (profile ee') to 0.5 (profile ii'). The largest transformation in all the analyzed profiles occurred on the surface of the road, and the smallest occurred at road undercuts (profiles $\mathrm{dd}^{\prime}, \mathrm{ff}^{\prime}, \mathrm{gg}^{\prime}, \mathrm{jj}^{\prime}$ ).

\subsection{Rate of Erosion and Accumulation on the Studied Forest Road in the Years 2017-2019}

The analysis of the DoDs showed that in the first period of 2017-2018 the greatest relief changes occurred in the lower part of the road, where the development of a deep erosion gully took place. The maximum deepening of the road surface was locally up to $2 \mathrm{~m}$. In the second period, the highest erosion values were lower and reached approximately $1 \mathrm{~m}$ (Figure 6).

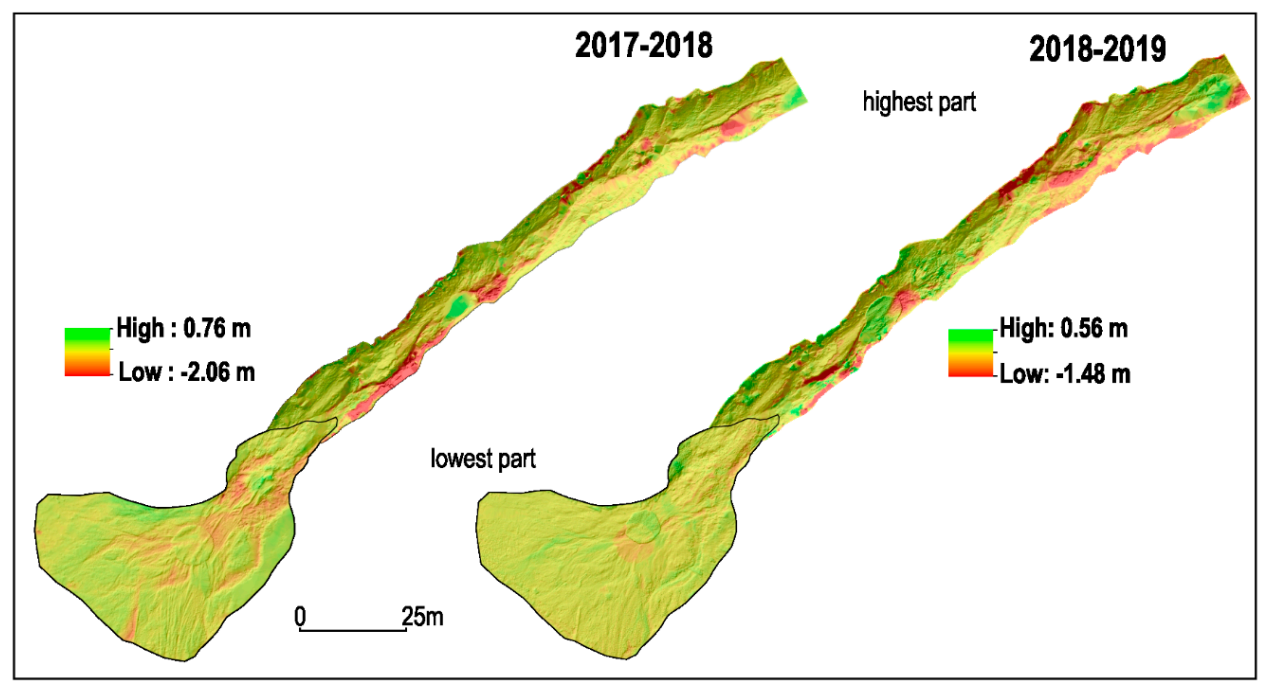

Figure 6. DEM of differences for the sections of forest road and accumulation fan in the period 2017-2018 and 2018-2019.

The rate of erosion in the period 2017-2018 in most of the studied road segments including the accumulation fan substantially exceeded the rate of accumulation (Figure 6). In the period 2017-2018, for the investigated road, the total erosion reached $1172 \mathrm{~m}^{3} \mathrm{ha}^{-1}$ year ${ }^{-1}$ and the total accumulation was $289 \mathrm{~m}^{3} \mathrm{ha}^{-1}$ year ${ }^{-1}$. Net erosion, calculated by subtracting the total accumulation from the total erosion equaled $884 \mathrm{~m}^{3} \mathrm{ha}^{-1}$ year ${ }^{-1}$. The total erosion and total accumulation for particular road segments equaled 322-3398 $\mathrm{m}^{3} \mathrm{ha}^{-1}$ year ${ }^{-1}$ and 31-1202 $\mathrm{m}^{3} \mathrm{ha}^{-1} \mathrm{year}^{-1}$, respectively. The average amount of change for all road segments was a lowering of $9 \mathrm{~cm}_{\text {year }}{ }^{-1}$. Spatial distribution of net erosion within forest road indicated that the greatest changes occurred in the lower part of the road (segments 4-7), with the maximum value of net erosion reaching $3286 \mathrm{~m}^{3} \mathrm{ha}^{-1}$ year ${ }^{-1}$ (Figure 7). The total erosion for the accumulation fan formed at the entrance of the road equaled $530 \mathrm{~m}^{3} \mathrm{ha}^{-1}$ year $\mathrm{y}^{-1}$ and the total accumulation equaled $265 \mathrm{~m}^{3} \mathrm{ha}^{-1}$ year ${ }^{-1}$, which gives net erosion of $265 \mathrm{~m}^{3} \mathrm{ha}^{-1}$ year ${ }^{-1}$. It is worth noting that the accumulation fan was used as a lumber storage site.

In the period 2018-2019 the total erosion for the whole road was lower comparing to the previous period and equaled $725 \mathrm{~m}^{3} \mathrm{ha}^{-1}$ year ${ }^{-1}$. However, the total accumulation remained at a similar level and was equal to $356 \mathrm{~m}^{3} \mathrm{ha}^{-1}$ year $^{-1}$. Net erosion was less than one half of its value in the previous monitoring period, at $370 \mathrm{~m}^{3} \mathrm{ha}^{-1}$ year-1. The total erosion and total accumulation for particular road segments equaled $83-2501 \mathrm{~m}^{3} \mathrm{ha}^{-1}$ year ${ }^{-1}$ and 7-928 $\mathrm{m}^{3} \mathrm{ha}^{-1}$ year ${ }^{-1}$, respectively. The average amount of change for all road segments was a lowering of $4.4 \mathrm{~cm}_{\text {year }}{ }^{-1}$. Compared to the previous period, the spatial distribution of the net erosion shows that the area with material accumulation (segments 1-4) is enlarged in the lower part, in the immediate vicinity of the accumulation fan. On the other hand, the zone with the highest net erosion value (segments 7-9) is moved to the upper part 
(Figure 7). However, the maximum net erosion value is lower than in the previous period and amounts to $2.494 \mathrm{~m}^{3} \mathrm{ha}^{-1}$ year ${ }^{-1}$.

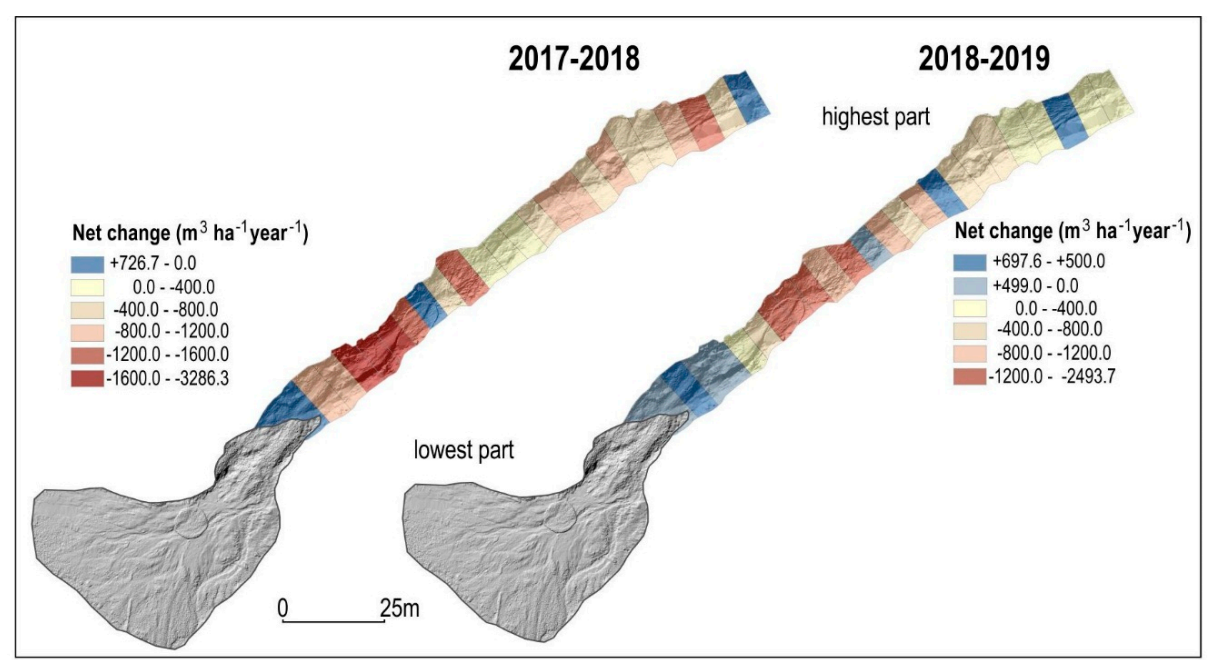

Figure 7. Net change on selected test surfaces within forest road between 2017-2018 and 2018-2019.

The total erosion within the accumulation fan during the second period equaled $117 \mathrm{~m}^{3} \mathrm{ha}^{-1}$ year ${ }^{-1}$ and the total accumulation equaled $153 \mathrm{~m}^{3} \mathrm{ha}^{-1}$ year $^{-1}$. Calculated by subtracting the total accumulation from the total erosion, the net accumulation within the accumulation fan was $36 \mathrm{~m}^{3} \mathrm{ha}^{-1}$ year $^{-1}$.

\subsection{Relationship between Average Flow Velocity and Net Erosion}

The studied forest road presently functions in the course of precipitation events as a periodic stream channel. The average flow velocity within erosion gully in 2017 for the segments underlain by rock outcrops (segments 1-18) was $0.62 \mathrm{~m} \mathrm{~s}^{-1}$, and the maximum value reached $0.91 \mathrm{~m} \mathrm{~s}^{-1}$. For segments with coarse rock material (segments 18-24) the average flow velocity was $0.34 \mathrm{~m} \mathrm{~s}^{-1}$, and the maximum value was $0.46 \mathrm{~m} \mathrm{~s}^{-1}$.

Significant correlation between flow velocity and net erosion was found. Flow velocity explains $28 \%$ of variation in the net erosion $\left(\mathrm{r}^{2}=0.28\right)$ (Figure 8$)$. This relationship is the most apparent in the lower part of the road (road segments 2, 4, 5, 7, 8).

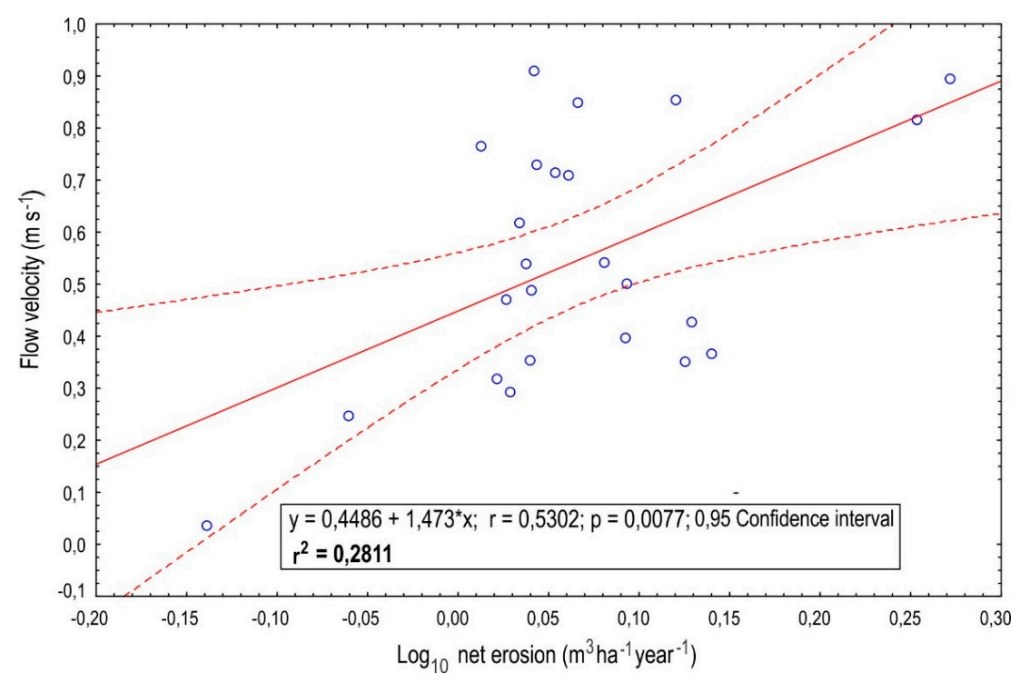

Figure 8. Relationship between the flow velocity and net erosion within the erosion gully formed within the investigated road. 


\section{Discussion}

\subsection{Magnitude of Erosion within Forest Roads-Data Comparison}

The rate of erosion for forest roads is significantly higher than that in areas with no human impact, i.e., with no forest roads [4,39-42]. In the tropical forests in Tekam Forest Reserve in Malaysia the average lowering of the ground in areas with no human impact was $6.29 \mathrm{~cm}^{\text {year }}{ }^{-1}$, while it was $39.14 \mathrm{~cm}_{\text {year }}{ }^{-1}$ on skid trails, and $54.52 \mathrm{~cm}_{\text {year }}{ }^{-1}$ on forest roads [6]. Other research has shown that the magnitude of erosion on heavily used forest roads is 130 times greater than on abandoned roads [5]. Moreover, significant differences were noted in the rate of erosion on roads, depending on the intensity of their use. A significant decrease in the rate of erosion on abandoned and steep sections of roads is also confirmed by other research [39]. Our study on the road in the first years after its abandonment indicates that the average rate of erosion is similar, and sometimes even greater than that on roads that are still in use (Table 2). An earlier study conducted in the studied area in 2016 showed that the mean rate of net road deepening equaled $4.5 \mathrm{~cm}_{\text {year }}{ }^{-1}$, and the maximum rate of deepening was $10 \mathrm{~cm}_{\text {year }}^{-1}$ [3]. In the Gorce Mountains (Poland) the mean rate of deepening of intensively used forest roads ranged from 0.08 to $4.14 \mathrm{~cm}_{\text {year }}{ }^{-1}$ [13]. In tropical forests in Peninsular Malaysia, where average annual precipitation is about $2654 \mathrm{~mm}$, the average rate of erosion associated with surface runoff on skid trails ranged from 2.4 to $3.1 \mathrm{~cm}$ year $^{-1}$ [7].

The changes noted along the studied road were significantly higher than those on tourist trails in the Carpathian Mountains (Table 2). Lower values are also found in other mountains. In the Karkonosze Mountains (Poland), the average rate of lowering of the surface of tourist trails is $1.09 \mathrm{~cm} \mathrm{year}^{-1}$, and the maximum rate is $2.1 \mathrm{~cm}_{\text {year }}{ }^{-1}$ [12]. On popular tourist trail in the Guadarrama Mountains (Spain) in the Senda Schmidt, where the average rainfall is about $1400 \mathrm{~mm}^{-1} \mathrm{ear}^{-1}$, the erosion rate reached from 0.17 to $0.26 \mathrm{~cm}$ year $^{-1}$ [43].

Table 2. Erosion rates for the studied forest road and other data in the Carpathian Mountains.

\begin{tabular}{|c|c|c|c|}
\hline & Net Change $^{\text {a }}$ & \multirow{2}{*}{ Study Area } & \multirow{2}{*}{ Author(s) } \\
\hline & $\left(\mathrm{cm}\right.$ year $\left.^{-1}\right)$ & & \\
\hline \multicolumn{4}{|c|}{ Form of Human Impact } \\
\hline $\begin{array}{c}\text { Forest road (first year } \\
\text { without human impact) }\end{array}$ & -9 (average) & Tatra Mts. (Poland) & Our research \\
\hline $\begin{array}{l}\text { Forest road (second year } \\
\text { without human impact) }\end{array}$ & -4.4 (average) & Tatra Mts. (Poland) & Our research \\
\hline Forest road & -4.5 (average) & Tatra Mts. (Poland) & [3] \\
\hline Forest roads & from -0.08 to -4.14 & Gorce Mts. (Poland) & [13] \\
\hline Tourist trail & $\begin{array}{l}\text { from }-2.3 \text { to }+2.5 \\
\quad-0.7 \text { (average) } \\
-0.9 \text { (average) }\end{array}$ & Gorce Mts. (Poland) & [45] \\
\hline $\begin{array}{c}\text { Tourist trail above } \\
\text { timberline }\end{array}$ & $\begin{array}{c}\text { from }-0.59 \text { to }-2.66 \\
-1.38 \text { (average) }\end{array}$ & $\begin{array}{l}\text { Western Carpathian Mts. } \\
\text { (Slovakia) }\end{array}$ & [46] \\
\hline \multicolumn{4}{|c|}{ Natural Processes and Landforms } \\
\hline $\begin{array}{c}\text { Gully erosion } \\
\text { Water erosion above } \\
\text { timberline }\end{array}$ & $\begin{array}{l}\text { from }-0.88 \text { to }-2.66 \\
\text { from }+0.012 \text { to }+0.072\end{array}$ & $\begin{array}{l}\text { Tatra Mts. and their } \\
\text { foreland (Slovakia) } \\
\text { High Tatra Mts., Belianske } \\
\text { Tatra Mts. (Slovakia) }\end{array}$ & [44] \\
\hline Avalanche chutes & -2.4 (average) & $\begin{array}{l}\text { Vel'ká Fatra Mts., } \\
\text { (Slovakia) }\end{array}$ & [47] \\
\hline Surface runoff & +0.893 (average) & $\begin{array}{l}\text { Western Tatra Mts. } \\
\text { (Slovakia) }\end{array}$ & [46] \\
\hline Nival niches & from -1 to -5 & High Tatra Mts. (Poland) & {$[48,49]$} \\
\hline
\end{tabular}


In studies conducted in the Slovak Tatra Mountains and their foreland, it was stated that erosion rate ranging from 0.5 to $1.5 \mathrm{~cm}_{\text {year }}{ }^{-1}$ should be considered very high, whereas rates $>1.5 \mathrm{~cm}_{\text {year }}{ }^{-1}$ should already be classified as catastrophic [44]. The rates of change noted for the studied road are also significantly higher compared to erosion rates found in areas with no human impact in the Carpathian Mountains (Table 2).

The magnitude of erosion on the studied road is greater than that on roads in other areas. Research conducted in Peninsular Malaysia, where during 16 months of research the total precipitation reached $3638 \mathrm{~mm}$, showed that erosion on forest roads was $266+/-20 \mathrm{~m}^{3} \mathrm{ha}^{-1}$ year $^{-1}$ [7]. In the same area the volumetric rate of erosion at timber storage sites equaled $139+/-10 \mathrm{~m}^{3} \mathrm{ha}^{-1}$ year ${ }^{-1}$ [7], which is lower than erosion within timber storage sites located in our study area during the first measurement period. On the other hand, the combined erosion rate for forest roads and lumber storage sites was 220-315 $\mathrm{m}^{3} \mathrm{ha}^{-1}$ for a $260 \mathrm{~mm}$ precipitation event which took place from 18-22, April 1983 in the Tairua Forest, New Zealand [50].

\subsection{Flow Velocity Relationship—Data Comparison}

Human intervention associated with the construction of forest roads and special logging roads in mountain areas contributes to an increase in the level of activity of selected geomorphologic processes occurring on hillslopes [51-53]. Gullies often develop in such areas. The gullies may completely change the circulation of water and matter on hillslopes. Such gullies function as flow channels during intense precipitation events. The rate of water flow after heavy rainfall events within gullies created as a result of the relief transformations along logging roads in the Karkonosze Mountains is about $1 \mathrm{~m} \mathrm{~s}^{-1}$ [52]. Our research indicates that the flow velocity is locally comparable for road segments with rock outcrops where the value comes to $0.91 \mathrm{~m} \mathrm{~s}^{-1}$. The values obtained for road segments with rock outcrops are close to flow rates obtained for unpaved roads on the Carpathians' flysch hillslopes, which exceed $1 \mathrm{~m} \mathrm{~s}^{-1}[53,54]$. However, the maximum average value, found in our research, is lower than the flow rate in small catchments in the Carpathians during flash floods, which ranges from 1.6 to $2 \mathrm{~m} \mathrm{~s}^{-1}$ [55].

Many studies conducted so far indicate that the magnitude of relief transformation depends on the slope inclination, surface resistance, intensity of road use and the occurrence of subsurface flow interception (ISSF) within the road cutslope $[3,5,8,56,57]$. Our research shows that the local conditions in a given road section, such as the local slope, type of surface and local morphology are also extremely important. In the longitudinal profile of the analyzed erosion gully within the road we can distinguish zones characterized by the presence of a sequence of accumulation steps, thresholds and evorsion kettles, and zones characterized by the exposed bedrock. In the sections with thresholds and evorsion kettles the flow velocities are decelerated below the thresholds, and, at the same time, high erosion values occur which is related to the development of evorsion kettles and headward erosion at the thresholds (cavitation). On the other hand, in the sections where bedrock is exposed, downward erosion is slowed down and lateral erosion then becomes more active. This regularity was demonstrated by the correlation between flow velocity and net erosion within the erosion gully at the lower part of the studied road (Figure $2 \mathrm{~b}, \mathrm{~d}, \mathrm{e}$ ). In turn, the sections where there is a high flow velocity and low erosion are characterized by the presence of wide zones with rock outcrops, which limits the erosion processes.

The uniqueness of mountain areas, especially their natural conditions and different intensity and type of human impact, may affect the way they function and make them different from other mountain areas $[6,7,14,58]$. This is why research is necessary on different spatial and temporal scales, which allows one to gain an in-depth knowledge of the principles that govern the transformation of mountain areas. Conclusions drawn in such research work may be helpful in the management of mountain areas.

\subsection{Management Practices within Forest Roads—Selected Aspects}

Forest management may contribute to significant relief transformation within a short period of time [12]. Research indicate that erosional processes along logging roads and forest roads are strongest in the first period immediately following their construction $[6,58,59]$. Research has shown that in the 
second year after the construction of forest roads, erosion along roads can decrease by $77 \%$, and along skid trails by $80 \%$ [6]. Others have found that erosion in the first period following the construction of forest roads is, on average, four times as much as in subsequent seasons [60]. A decrease in the magnitude of erosion in the seasons following the construction of a new road was also noted [59]. The greatest transformation of relief on the investigated road occurred in the third season following the construction of this road, and contributed to its abandonment. These transformations were caused by improper design of the road, which crossed runoff convergence area, low resistance of rocks in the substratum, and occurrence of a heavy rainfall event [3]. Research conducted four years after the construction of a new road segment in the Hengduan Mountains indicates the presence of massive erosion, the rate of which was incomparably higher than the rates specified for other areas of the world [61]. The researchers also indicated that massive erosion was caused by the construction of a road without any detailed prior analysis of its geomorphologic location and threats related to the activity of natural processes in the area.

In order to minimize the negative impact of forest roads and logging roads on the local natural environment, it is important that their planning and construction be performed only after an analysis of natural conditions of a given area is performed $[17,19,57,62,63]$. Another important aspect is that lumber transportation techniques should be suitable for a given set of terrain conditions-a cable crane may be used for instance $[56,64,65]$. This kind of approach may contribute to a "development without destruction" $[17,66]$. The monitoring of forest roads should be continued even after cessation of use, as their terrain may continue to undergo successive changes due to erosional processes [26]. Such an approach may limit intense and irreversible transformation of relief $[67,68]$.

Our research has shown that the use of the TLS may contribute to better understanding of a given road development. Precise measurements enable determining and comparing flow velocities, which in turn allows to roughly predict further erosion rates. Detailed identification of natural conditions may be crucial in applying effective anti-erosion treatments. In order to limit excessive erosion, it is extremely important to slow down the flow velocity, e.g., by creating drainage systems or arranging rock blocks in a way that disperses the excessive flow energy. Research has shown that proper maintenance and control of the condition of a forest road within the period of 5 years after its construction, are of key significance in minimizing erosion along the road [69]. The proper drainage of water from roads is a highly effective technique in limiting excessive erosion [39]. Forest management in the United States, including forest road construction and maintenance, is accomplished based on so-called forestry best management practices (BMPs) established by state forestry agencies, which yields a well-informed management plan for forest areas [2].

\section{Conclusions}

Forest roads may cause substantial transformation of relief, even after their abandonment. The net annual change on the studied road equaled $-884 \mathrm{~m}^{3} \mathrm{ha}^{-1}$ year-1 for the first measurement period, and $-370 \mathrm{~m}^{3} \mathrm{ha}^{-1}$ year ${ }^{-1}$ for the second measurement period. The surface of the whole road was lowering at the rate of $9 \mathrm{~cm}_{\text {year }}{ }^{-1}$ and $4.4 \mathrm{~cm}_{\text {year }}{ }^{-1}$, respectively for the first and the second measurement periods. Furthermore, changes across the accumulation fan were from $-265.13 \mathrm{~m}^{3} \mathrm{ha}^{-1}$ year $^{-1}$ to $+35.9 \mathrm{~m}^{3} \mathrm{ha}^{-1}$ year $^{-1}$. The amount of material removed from the accumulation fan was $2.7 \mathrm{~cm}$ year ${ }^{-1}$ and amount of accumulation was $0.4 \mathrm{~cm}_{\text {year }}{ }^{-1}$. The average rate of erosion for the studied road no longer in use is similar, and sometimes even greater than that for roads still in use. Forest roads may function similarly to gullies with similar flow rates. Research has shown that there is a significant relationship $\left(r^{2}=0.28\right)$ between the flow velocity and the magnitude of net erosion within the studied forest road.

Author Contributions: Conceptualization, J.F.-O. and D.S.; methodology, D.S., J.C., and D.W.-W.; Formal analysis, J.F.-O., D.S., J.C., and D.W.-W.; Investigation, J.F.-O., D.S., and J.C.; Writing-original draft preparation, J.F.-O. and D.S.; Writing - review and editing, J.F.-O., D.S., J.C., and D.W.-W.; Visualization, J.F.-O. and D.S.; Funding acquisition, J.F.-O. All authors have read and agreed to the published version of the manuscript. 
Funding: This research was funded by the Pedagogical University of Cracow (Poland), project number BN.610-193/PBU/2020.

Acknowledgments: We would like to thank the Tatra National Park for the opportunity to conduct this research. We would like to thank the Institute of Geography and Spatial Organization, Polish Academy of Sciences for the opportunity to use the terrestrial laser scanner.

Conflicts of Interest: The authors declare no conflict of interest.

Data Availability Statement: Public meteorological data was obtained from the Polish Institute of Meteorology and Water Management - National Research Institute https://danepubliczne.imgw.pl/datastore.

\section{References}

1. $\quad$ Łukasik, W.; Kubiesa, P.; Staszewski, T. Erosion processes initialized by use of heavy equipment in mountain forests of the Wilczy Potok catchment, Silesian Beskids. Arch. Environ. Protect. 2016, 42, 80-86. [CrossRef]

2. Cristan, R.; Aust, W.M.; Bolding, M.C.; Barrett, S.M.; Munsell, J.F.; Schilling, E. Effectiveness of forestry best management practices in the United States: Literature review. Forest Ecol. Manag. 2016, 360, 133-151. [CrossRef]

3. Fidelus-Orzechowska, J.; Strzyżowski, D.; Żelazny, M. The geomorphic activity of forest roads and its dependencies in the Tatra Mountains. Geogr. Annal. Ser. A Phys. Geogr. 2018, 100, 59-74. [CrossRef]

4. Reid, L.M.; Dunne, T.; Cederholm, C.J. Application of sediment budget studies to the evaluation of logging road impact. J. Hydrol. (N. Z.) 1981, 20, 49-62.

5. Reid, L.M.; Dunne, T. Sediment production from forest road surfaces. Water Resour. Res. 1984, 20, $1753-1761$. [CrossRef]

6. Baharuddin, K.; Mokhtaruddin, A.M.; Muhamad, M.N. Surface runoff and soil loss from a skid trail and a logging road in a tropical forest. J. Trop. For. Sci. 1995, 7, 558-569.

7. Sidle, C.R.; Sasaki, S.; Otsuki, M.; Noguchi, S.; Nik, A.R. Sediment pathways in a tropical forest: Effects of logging roads and skid trails. Hydrol. Process. 2004, 18, 703-720. [CrossRef]

8. Negishi, J.N.; Sidle, R.C.; Ziegler, A.D.; Noguchi, S.; Rahim, N.A. Contribution of intercepted subsurface flow to road runoff and sediment transport in a logging-disturbed tropical catchment. Earth Surf. Process. Landf. J. Br. Geomorphol. Res. Group 2008, 33, 1174-1191. [CrossRef]

9. Dutton, A.L.; Loague, K.; Wemple, B.C. Simulated effect of a forest road on near-surface hydrologic response and slope stability. Earth Surf. Process. Landf. J. Br. Geomorphol. Res. Group 2005, 30, 325-338. [CrossRef]

10. Soulis, K.X.; Dercas, N.; Papadaki, C.H. Effects of forest roads on the hydrological response of a small-scale mountain watershed in Greece. Hydrol. Process. 2015, 29, 1772-1782. [CrossRef]

11. Thomaz, E.L.; Peretto, G.T. Hydrogeomorphic connectivity on roads crossing in rural headwaters and its effect on stream dynamics. Sci. Total Environ. 2016, 550, 547-555. [CrossRef]

12. Kasprzak, M. Tempo degradacji powierzchni dróg i ścieżek turystycznych w Karkonoszach Wschodnich [The rate of degradation of tourist routes in the East Gian mountains]. Opera Corcon. 2005, 42, 17-30.

13. Wałdykowski, P.; Krzemien, K. The role of road and footpath networks in shaping the relief of middle mountains on the example of the Gorce Mountains (Poland). Z. Geomorphol. 2013, 57, 429-470. [CrossRef]

14. Wemple, C.B.; Swanson, J.F.; Jones, J.A. Forest roads and geomorphic processes interactions, Cascade Range, Oregon. Earth Surf. Process. Landf. 2001, 26, 191-204. [CrossRef]

15. Borga, M.; Tonelli, F.; Selleroni, J. A physically based model of the effects of forest roads on slope stability. Water Resour. Res. 2004, 40,1-9. [CrossRef]

16. Borga, M.; Tonelli, F.; Dalla Fontana, G.; Cazorzi, F. Evaluating the influence of forest roads on shallow landsliding. Ecol. Modell. 2005, 187, 85-98. [CrossRef]

17. Safari, A.; Kavian, A.; Parsakhoo, A.; Saleh, I.; Jordán, A. Impact of different parts of skid trails on runoff and soil erosion in the Hyrcanian forest (northern Iran). Geoderma 2016, 263, 161-167. [CrossRef]

18. Kleinschroth, F.; Healey, J.R. Impacts of logging roads on tropical forests. Biotropica 2017, 49, 620-635. [CrossRef]

19. Demir, M. Impacts, management and functional planning criterion of forest road network system in Turkey. Transp. Res. Part A Policy Practice 2007, 41, 56-68. [CrossRef]

20. Tittler, R.; Messier, C.; Fall, A. Concentrating anthropogenic disturbance to balance ecological and economic values: Applications to forest management. Ecol. Appl. 2012, 22, 1268-1277. [CrossRef] 
21. Ioraş, F.; Muica, N.; Turnock, D. Approaches to sustainable forestry in the Piatra Craiului National Park. GeoJournal 2001, 55, 579-598. [CrossRef]

22. Kräuchi, N.; Brang, P.; Schönenberger, W. Forests of mountainous regions: Gaps in knowledge and research needs. For. Ecol. Manag. 2000, 132, 73-82. [CrossRef]

23. Tarolli, P.; Calligaro, S.; Cazorzi, F.; Fontana, G.D. Recognition of surface flow processes influenced by roads and trails in mountain areas using high-resolution topography. Eur. J. Remote Sens. 2013, 46, 176-197. [CrossRef]

24. Dąbek, P.B.; Patrzałek, C.; Ćmielewski, B.; Żmuda, R. The use of terrestrial laser scanning in monitoring and analyses of erosion phenomena in natural and anthropogenically transformed areas. Cogent Geosci. 2018, 4, 1437684. [CrossRef]

25. Dąbek, P.B.; Żmuda, R.; Szczepański, J.; Ćmielewski, B. Evaluation of water soil erosion processes in forest areas in the Western Sudetes using terrestrial laser scanning and GIS tools. E3S Web Conf. 2018, 44, 26. [CrossRef]

26. Yurtseven, H.; Akgul, M.; Akay, A.O.; Akburak, S.; Cigizoglu, H.K.; Demir, M.; Ozturk, T.; Eksi, M. High accuracy monitoring system to estimate forest road surface degradation on horizontal curves. Environ. Monit. Assess. 2019, 191,1-17. [CrossRef] [PubMed]

27. Dąbek, P.; Żmuda, R.; Ćmielewski, B.; Szczepański, J. Analysis of water erosion processes using terrestrial laser scanning. Acta Geodynam. Geomater. 2014, 11, 45-52. [CrossRef]

28. Akgul, M.; Yurtseven, H.; Akburak, S.; Demir, M.; Cigizoglu, H.K.; Ozturk, T.; Eksi, M.; Akay, A.O. Short term monitoring of forest road pavement degradation using terrestrial laser scanning. Measurement 2017, 103, 283-293. [CrossRef]

29. Akay, A.O.; Akgul, M.; Demir, M. Determination of temporal changes on forest road pavement with terrestrial laser scanner. Fresenius Environ. Bull. 2018, 27, 1437-1448.

30. Ferraz, A.; Mallet, C.; Chehata, N. Large-scale road detection in forested mountainous areas using airborne topographic lidar data. ISPRS J. Photogramm. Remote Sens. 2016, 112, 23-36. [CrossRef]

31. Affek, A.N.; Zachwatowicz, M.; Sosnowska, A.; Gerlée, A.; Kiszka, K. Impacts of modern mechanised skidding on the natural and cultural heritage of the Polish Carpathian Mountains. For. Ecol. Manag. 2017, 405, 391-403. [CrossRef]

32. Miller, J.R.; Joyce, L.A.; Knight, R.L.; King, R.M. Forest roads and landscape structure in the southern Rocky Mountains. Landsc. Ecol. 1996, 11, 115-127. [CrossRef]

33. Lugo, A.E.; Gucinski, H. Function, effects, and management of forest roads. For. Ecol. Manag. 2000, 133, 249-262. [CrossRef]

34. Strzyżowski, D.; Fidelus, J.; Żelazny, M. Sediment transport by uprooting in the forested part of the Tatra Mountains, southern Poland. Catena 2018, 160, 329-338. [CrossRef]

35. Ustrnul, Z.; Walawender, E.; Czekierda, D.; Št'astný, P.; Lapin, M.; Mikulová, K. Opady atmosferyczne i pokrywa śnieżna. In Atlas Tatr. Przyroda Nieożywiona: II.3; Tatrzański Park Narodowy: Zakopane, Poland, 2015; ISBN 978-83-61788-91-1.

36. Hess, M. Piętra klimatyczne Tatr [Climatic zones in the Tatra Mountains]. Czas. Geogr. 1974, 45, 75-93.

37. Żmudzka, E.; Nejedlík, P.; Mikulová, K. Temperatura, wskaźniki termiczne. In Atlas Tatr. Przyroda nieożywiona: II.2; Tatrzański Park Narodowy: Zakopane, Poland, 2015; ISBN 978-83-61788-91-1.

38. Chow, V.T. Open-Channel Hydraulics; Mc-Graw-Hill: New York, NY, USA, 1959.

39. Ramos-Scharrón, C.E.; MacDonald, L.H. Measurement and prediction of natural and anthropogenic sediment sources, St. John, US Virgin Islands. Catena 2007, 71, 250-266. [CrossRef]

40. MacDonald, L.H.; Coe, D.B. Road sediment production and delivery: Processes and management. In Proceedings of the First World Landslide Forum, International Programme on Landslides and International Strategy for Disaster Reduction, Tokyo, Japan, 18-21 November 2008; pp. 381-384.

41. Scharrón, C.E.R. Sediment production from unpaved roads in a sub-tropical dry setting-Southwestern Puerto Rico. Catena 2010, 82, 146-158. [CrossRef]

42. Zemke, J.J. Runoff and soil erosion assessment on forest roads using a small scale rainfall simulator. Hydrology 2016, 3, 25. [CrossRef]

43. Bodoque, J.M.; Díez-Herrero, A.; Martín-Duque, J.F.; Rubiales, J.M.; Godfrey, A.; Pedraza, J.; Carrasco, R.M.; Sanz, M.A. Sheet erosion rates determined by using dendrogeomorphological analysis of exposed tree roots: Two examples from Central Spain. Catena 2005, 64, 81-102. [CrossRef] 
44. Midriak, R. Quantitative analysis of natural hazards in the eastern part of the Slovak Tatra mountains and their foreland. Stud. Geomorphol. Carpatho-Balc. 2017, 51/52, 139-154.

45. Tomczyk, A.M.; Ewertowski, M. Quantifying short-term surface changes on recreational trails: The use of topographic surveys and 'digital elevation models of differences'(DODs). Geomorphology 2013, 183, 58-72. [CrossRef]

46. Midriak, R. Present-day retreat of slopes above the upper timberline in the Slovak part of the Western Carpathians. Geogr. Polonica 2008, 81, 93-100.

47. Lepeška, T. Dynamics of development and variability of surface degradation in the subalpine and alpine zones (an example from the Velká Fatra Mts., Slovakia). Open Geosci. 2016, 8, 771-786. [CrossRef]

48. Raczkowska, Z. Nivation in the high Tatras, Poland. Geogr. Annal. Ser. A Phys. Geogr. 1995, 77, $251-258$. [CrossRef]

49. Raczkowska, Z. Nivation and its geomorphic significance-Examples from the Polish High Tatra and the Ortles-Cevedale Massif, the Italian Alps. Stud. Geomorphol. Carpatho-Balc. 1997, 31, 175-192.

50. Pearce, A.J.; Hodgkiss, P.D. Erosion and sediment yield from a landing failure after a moderate rainstorm, Tairua Forest. N. Z. J. For. 1987, 32, 19-22.

51. Gerrard, A.J. Mountain Environment: An Examination of the Physical Geography of Mountains; Belhaven Press: London, UK, 1970; p. 317.

52. Parzóch, K. Procesy erozyjne na stokach wylesionych w Karkonoszach [Erosion processes on deforested slopes in the Karkonosze Mts]. Zesz. Probl. Postẹp. Nauk Rol. 2002, 487, 239-247.

53. Bryndal, T.; Kroczak, R. Reconstruction and characterization of the surface drainage system functioning during extreme rainfall: The analysis with use of the ALS-LIDAR data-The case study in two small flysch catchments (Outer Carpathian, Poland). Environ. Earth Sci. 2019, 78, 215. [CrossRef]

54. Figuła, K. Preliminary assessment of erosion on the several districts of the Krakowskie province. Rocz. Nauk Rol. 1955, 1, 1-80.

55. Bryndal, T.; Franczak, P.; Kroczak, R.; Cabaj, W.; Kołodziej, A. The impact of extreme rainfall and flash floods on the flood risk management process and geomorphological changes in small Carpathian catchments: A case study of the Kasiniczanka river (Outer Carpathians, Poland). Nat. Hazards 2017, 88, 95-120. [CrossRef]

56. Byblyuk, N.; Styranivsky, O.; Korzhov, V.; Kudra, V. Timber harvesting in the Ukrainian Carpathians: Ecological problems and methods to solve them. J. For. Sci. 2010, 56, 333-340. [CrossRef]

57. Akbarimehr, M.; Naghdi, R. Reducing erosion from forest roads and skid trails by management practices. J. For. Sci. 2012, 58, 165-169. [CrossRef]

58. Sidle, R.C.; Ziegler, A.D.; Negishi, J.N.; Nik, A.R.; Siew, R.; Turkelboom, F. Erosion processes in steep terrain—truths, myths, and uncertainties related to forest management in Southeast Asia. For. Ecol. Manag. 2006, 224, 199-225. [CrossRef]

59. Croke, J.; Hairsine, P.; Fogarty, P. Soil recovery from track construction and harvesting changes in surface infiltration, erosion and delivery rates with time. For. Ecol. Manag. 2001, 143, 3-12. [CrossRef]

60. Megahan, W.F.; Wilson, M.; Monsen, S.B. Sediment production from granitic cutslopes on forest roads in Idaho, USA. Earth Surf. Process. Landf. 2001, 26, 153-163. [CrossRef]

61. Sidle, R.C.; Furuichi, T.; Kono, Y. Unprecedented rates of landslide and surface erosion along a newly constructed road in Yunnan, China. Nat. Hazards 2011, 57, 313-326. [CrossRef]

62. Abdi, E.; Majnounian, B.; Darvishsefat, A.; Mashayekhi, Z.; Sessions, J. A GIS-MCE based model for forest road planning. J. For. Sci. 2009, 55, 171-176. [CrossRef]

63. Jaafari, A.; Najafi, A.; Rezaeian, J.; Sattarian, A.; Ghajar, I. Planning road networks in landslide-prone areas: A case study from the northern forests of Iran. Land Use Policy 2015, 47, 198-208. [CrossRef]

64. Košir, B.; Krč, J. Where to Place and Build Forest Roads-Experience from the Model. J. For. Eng. 2000, 11, 7-19.

65. Enache, A.; Kühmaier, M.; Visser, R.; Stampfer, K. Forestry operations in the European mountains: A study of current practices and efficiency gaps. Scand. J. For. Res. 2016, 31, 412-427. [CrossRef]

66. Lewis, S.L.; Edwards, D.P.; Galbraith, D. Increasing human dominance of tropical forests. Science 2015, 349, 827-832. [CrossRef] [PubMed]

67. Swift, L.W. Forest access roads: Design, maintenance, and soil loss. In Forest Hydrology and Ecology at Coweeta; Springer: New York, NY, USA, 1988; pp. 313-324.

68. Burroughs, E.R., Jr.; King, J.G. Reduction of Soil Erosion on Forest Roads; USDA Forest Service: Washinghton, DC, USA; UNL Faculty Publications: Lincoln, NE, USA, 1989; pp. 1-22. 
69. Yousefi, S.; Moradi, H.; Boll, J.; Schönbrodt-Stitt, S. Effects of road construction on soil degradation and nutrient transport in Caspian Hyrcanian mixed forests. Geoderma 2016, 284, 103-112. [CrossRef]

Publisher's Note: MDPI stays neutral with regard to jurisdictional claims in published maps and institutional affiliations.

(C) 2020 by the authors. Licensee MDPI, Basel, Switzerland. This article is an open access article distributed under the terms and conditions of the Creative Commons Attribution (CC BY) license (http://creativecommons.org/licenses/by/4.0/). 